ELS Journal on Interdisciplinary Studies on Humanities

Volume 1 Issue 3, 2018

ISSN (print) : 2621-0843

ISSN (online) : 2621-0835

Homepage : http://journal.unhas.ac.id/index.php/jish

\title{
Problems on English Word Stress Placement Made by Indonesian Learners of English
}

\author{
Sukardi Weda ${ }^{1^{*}}$
}

sukardi.weda@unm.ac.id

\begin{abstract}
This study focuses its investigation on the problems of stress placement in English words made by Indonesian learners of English (ILE). The subjects of the study were the students of English Literature Study Program Universitas Negeri Makassar ( $N=66,20$ or $30.30 \%$ males and 46 or 69.69 females). Results of the study show that the Indonesian learners of English (ILE) were able to put the an acute accent (') illustrating the primary stress on monosyllabic words (one syllable words) easily; two syllable words, except for word permit; three syllable words, except for the word determine; words with suffixes in reading test; words with prefixes, except for word imbalance; compound words, except for word sunrise; noun phrases; stress on verbs and stress on nouns. The ILE were not able to put an acute accent (') illustrating the main stress on polysyllabic words with suffixes in written test, but the ILE has excellent competence for the words objectivity and disagreement. The ILE therefore tended to put the correct stress placement on reading test than on written test. The ILE often mistress the words in polysyllabic words, like: permit, determine, imbalance, accuracy, anchorage, etc. Additionally, descriptive statistics shows the percentage of correct and incorrect pronunciation made by Indonesian Learners of English (ILE) in recording and written test. The educational implication of this study is that the practice for stress placement of words, ranging from monosyllabic words to polysyllabic words needs to be taught in English learning and teaching process in the classroom setting. This in keeping with the results of the questionnaires that 'Learning correct stress placement needs large portion in EFL classroom' with a mean 3.6061 and $S D=.87493$ and 'Correct stress placement on words is important' with a mean of 4.1515 and $S D=.68483$.

Keywords: Pronunciation problems, stress, stress placement, English, ILE.
\end{abstract}

Keywords: Speaking, Perceptions, Creating Videos

How to cite: Weda, S. (2018). Problems on English Word Stress Placement Made by Indonesian Learners of English. ELS Journal on Interdisciplinary Studies in Humanities, 1(3), 328-341.

\section{Introduction}

Each language has uniqueness and one of the uniqueness of English is its pronunciation. Its spelling is different with its pronunciation. Language learners and linguists strongly agree that either segmental and supra segmental features of English are difficult to be pronounced (Weda \& Sakti, 2018: 1). As English learners, Indonesian speakers of English meet difficulties in pronouncing English words (Weda \& Sakti, 2018: 2643). One of the intriguing phenomena of pronouncing sounds in different languages is mispronunciation because the speakers of one language sometimes feel difficulties to pronounce words or sounds. The speaker of language A sometimes meets difficulties in pronouncing the sounds of language B but the speaker of language B can produce the sounds of language A easily (Weda, 2017:

\footnotetext{
${ }^{1}$ Universitas Negeri Makassar
} 
15). As an example is Indonesian speakers of English can produce [ $\mathrm{n}$ ] and [n] sound at the beginning of a word easily. This is because in Indonesian, these sounds are notably uttered in every day communication which appears in the words: nambek, nilu, nomong, nompol and nambi, nanyi, nontek in which this sounds are absent at the beginning of a word in English. The speakers of English meet difficulties to pronounce these sounds. In keeping with this, Fromkin, Rodman, \& Hyams, 2007) exemplify that a sound such [ $\mathrm{\eta}$ ] is difficult for an English speaker to pronounce at the beginning of a word but easy for a Vietnamese speaker means that there is no general notion of "difficulty of articulation" that can explain all of the sound patterns of particular language.

Languages differ not only in their inventory of speech segments (vowels and consonants) but also in their use of different suprasegmental features or prosodic systems such as tone, pitch-accent and stress to signal lexical contrasts (Wayland, Guion, Landfair, \& Li, 2006: 1).

The pronunciation of English poses many problems of a different kind from those which we face when we learn our first language (Weda, 2017: 15). This is because English tends to be a stress-timed language with rhythmic patterns based on a fairly regular recurrence of stressed syllables (Bolinger in Dieu, 2015: 52). English, along with other languages such as Russian and Arabic, belongs to a group of languages which are described as 'stress-timed' languages (Abercrombie in Checklin, 2012: 1). These languages' syllables are not equally stressed: some are more prominent, others have less prominence and some have none at all; and this system of stress-timing lies at the root of the whole suprasegmental system of English (Dickerson in Checklin, 2012: 1-2). In stress-timed languages, it is claimed that the stress syllables recur at regular intervals of time, regardless of the number of intervening unstressed syllables, as in English (Crystal, 1987: 289).

The L2 acquisition of word stress studies has become interesting research topics in phonetics and phonology. Some of the researchers who focused their study on the acquisition of English as a foreign language (EFL) or a second language (L2) and the English word stress for non-native speakers of English emerged (Kawagoe, Itsue, 2002; Weda, Sukardi, 2012; Karjo, C, 2016; Gralinska-Brawata \& Rybinska, 2017; Liu, Dan, 2017; Wayland, Ratree, Guion, Susan G, Landfair, David, \& Li, Bin, 2006; Archibald, John, 1994; Flege, James Emil \& Bohn, Ocke-Schwen, 1989; Guion, Susan G, Harada, Tetsuo, \& Clark, J.J, 2004; and Guion, Susan G, 2005). The L2 acquisition of word stress is a major part that is understudied (Liu, 2017: 1). Moedjito (2008) argues that in Indonesian context, English pronunciation has rather been neglected, for example, the teaching of English pronunciation tends to have an insufficient portion.

Learning the pronunciation of a foreign language involves not only the segments, i.e. the sounds of the $L 2$, but also the acquisition of suprasegmentals, e.g. the placement of stress or the intonation (Liu, 2017: 1). Incorrect placement of primary stress in L2 words may lead to the breakdown of communication (Liu, 2017: 1). Word stress is an essential element of English language learning as it affects the comprehension and intelligibility of spoken English (Gralinska-Brawata and Rybinska, 2017).

The accuracy of acceptability of stress in utterances will give a clear signal to the listeners, and improve the quality of speakers' utterances (Weda \& Sakti, 2017: 15). One of the five phonological factors causing stress placement errors is 
mispronunciation (Karjo, 2016). Karjo therefore adds that misplacement of stress is caused by, among others are the influence of vowel length, vowel height, misidentification of syllable structure, and the influence of orthogrpic form of the words (Karjo, 2016: 207).

\section{Review of Literature}

\subsection{Stress}

Stress is the degree of force used in producing a syllable (Crystal, 1987: 288). Ladefoged (Weda, 1998: 6) argues that stress as a suprasegmental feature of utterances: it applies not to individual vowels and consonants but to whole syllables whatever they might be. A stress syllable is pronounced with a greater amount of energy than an unstressed syllable (Weda, 1998: 6). Ladefoged (Weda, 1998: 6) therefore adds that a stress syllable is produced by pushing more air out of the lungs in one syllable relative to others.

Stress and rhythm are suprasegmental aspects that give the overall shape to the word or sequence (Sabater, 1991: 1). She therefore claims that if easy intelligibility is to be achieved, it is important to give words their correct accentual pattern and rhythm. Thus, the example of pronunciation of a word with the inappropriate accentual and rhtyhmic pattern is as follows (Sabater, 1991: 1):

vocabulary [və'kæsbjuləri] as [voka'bjulari]

profitable ['profítəbl] as [profi'teibol]

makes the word unintelligible not only because the misplaced main stress distorts the shape of the word, but also because there is no unstressing of the other syllables with the consequent phonetic reductions.

English speakers make many uses of stress - in simplest terms, coming down harder on one segment in a word or sentence than on its neighbors (Herndon, 1976: 255). In many languages, including English, one or more of the syllables in every content word (i.e., every word except for function words like to, the, a, of are stressed (Fromkin, et al., 2007: 287). They therefore add that a stressed syllable, which can be marked by an acute accent ('), is perceived as more prominent than unstressed syllables in the following examples:

$\begin{array}{lll}\text { 'import (noun) } & \text { as in "The company buys some 'import goods from USA." } \\ \text { im'port } & \text { (verb) } & \text { as in "The company im'port these goods from USA." }\end{array}$

Some words may contain more than one stressed vowel, but exactly one of the stressed vowels is more prominent than the others (Fromkin, et al., 2007: 287). They further state that the other stressed vowels, other than primary stress or main stress are secondary stress which marked by a grave accent (") over the vowels.

\subsection{Level of Stress}

Following Jackson (Weda, 1998: 16), another good reason for recognizing syllables is that there is a further phenomenon that seems to be associated with them, that of stress placement. Jackson further states that when we hear polysyllabic words spoken we are often aware that some part of the word sounds louder or seems to be uttered with more force than another part. Or, to put it another way, one syllable is more prominent than another. 
Sukardi Weda. 1(3): $328-341$

In English words, we usually recognize three degrees of stress: primary stress, indicated by a stroke above the line at the beginning of the syllable so stressed ('); secondary stress, indicated by a stroke on or below the line at the beginning of the syllable so stressed, and unstressed syllable, which is not marked (Jackson in Weda 1998: 16).

\subsection{The Basic Rules}

Fudge (Weda, 2012: 25-26) presents the rules of identifying stress. If the stress portion (SP) is monosyllabic, there is no choice of stress placement: The single syllable receives stress, e.g. ship, eat, and man. If the SP is dissylabic, stress is normally penultimate, e.g. Ozon, Arab, permit, import. If the words are verbs, the basic rule is that if the second syllable of the verb contains a long vowels or diphthongs, of if it ends with more than one consonant, the second syllable is stressed, e.g. apply, arrive, attract. If the final syllable contains a short vowel and one (or no final consonant), the first syllable is stressed, e.g. enter, equal, envy. A final syllable is also unstressed if it contains əひ, e.g. follow, borrow. If the SP is trisyllabic or longer, its stress is either penultimate or antepenultimate, depending on a number of factors. a) if the final syllable is strong, it means the final syllable gets emphasis, so stress falls two syllables back from that syllable, i.e, three syllables from the end of the SP of the word, as in: antelope, cummerbund, b) if the final syllable is weak, it means the final syllable does not get emphasis, then: i) if the penultimate syllable is strong, then it is stressed as in verandah, spaghetti; ii) if the penultimate syllable is weak, then the syllable before it is stressed, as in asparagus, America. In verbs, if the last syllable contains a short vowel and ends with no more than one consonant, that syllable will be unstressed and stress will be placed on the penultimate, e.g. encounter, determine.

If the final syllable contains a long vowel or diphthong, or ends with more than one consonant, that final syllable will be stressed, as in entertain, resurrect. Again, in nouns, if the final syllable contains a short vowel or diphthong, or if it ends with more than one consonant, that middle syllable will be stressed as in potato, disaster.

Fudge (Weda, 2012: 26) adds that certain words exhibit different stress patterns depending on whether they are nouns or verbs. There are some pairs of two syllable words with identical spelling which differ from each other in stress placement, apparently according to noun and verb. Examples are as follows:

Table 1. Noun-Verb Pairs

\begin{tabular}{ccc}
\hline Verb & Noun & Notes \\
\hline import & import & \\
protest & protest & \\
subject & subject & \\
address & address & Initial syllable or verbs are \\
present & present & reduced, and in nouns, their \\
desert & desert & final syllables are reduced \\
absent & absent & \\
permit & permit & \\
etc. & etc. & \\
\hline
\end{tabular}




\section{Method}

\subsection{Subjects}

The subjects of the study were 66 students at the English Literature Study Program Faculty of Languages and Literature Universitas Negeri Makassar, 20 or $30.30 \%$ males and 46 or 69.69 females, between the 17 and 20 ages, 1 or $1.51 \%$ of the student is 17 years old, 34 or $51.51 \%$ of the students are 18 years old, 26 or $39.39 \%$ of the students are 19 years old, and 5 or $7.57 \%$ of them are 20 years old. The subjects were registered in the second semester and attended Pronunciation Practice subject.

Table 2. Subjects' Information

\begin{tabular}{ccccc}
\hline School Level & Major & Semester & N & Gender \\
\hline University & $\begin{array}{c}\text { English } \\
\text { Literature } \\
\text { Study Program }\end{array}$ & $2^{\text {nd }}$ Semester & 66 & 20 males, \\
& & & 46 females \\
\hline
\end{tabular}

\subsection{Materials and Procedures}

The subjects involved in reading a corpus of words presented in the lists. Procedures were the subjects were asked to read the target words in the lists consisting of one syllable words (monosyllabic words) to polysyllabic words as revealed in table 2 which were obtained from Weda (2012: 25-26). While the subjects were reading target words in the lists, the researcher recorded their pronunciation using audio recording. Another procedure to gain the data was asking the subjects to put an acute accent (') illustrating the primary stress above the syllable.

Table 3. List of Words in Pronunciation Testing

\begin{tabular}{ccccc}
\hline $\begin{array}{c}\text { Single } \\
\text { Syllable } \\
\text { Words }\end{array}$ & $\begin{array}{c}\text { Dissyllabic } \\
\text { Words }\end{array}$ & $\begin{array}{c}\text { Trisyllabic } \\
\text { Words }\end{array}$ & $\begin{array}{c}\text { Stress with } \\
\text { Suffixes }\end{array}$ & $\begin{array}{c}\text { Stress with } \\
\text { Prefixes }\end{array}$ \\
\hline ship & ozon & antelope & accuracy & improper \\
\hline eat & Arab & cummerbund & anchorage & improbable \\
\hline man & permit & verandah & budgetary & befriend \\
\hline apply & spaghetti & disagreement & becalm \\
\hline arrive & America & politeness & dislike \\
\hline attract & encounter & prestigious & exservice \\
\hline enter & determine & advantageous & incorrect \\
\hline equal & entertain & photography & illogical \\
\hline envy & resurrect & objectivity & uncomfortable \\
\hline follow & potato & modernist & irrational \\
\hline borrow & disaster & neighborhood & imbalance \\
\hline & \multicolumn{3}{c}{}
\end{tabular}

Table 4. List of Compounds and Noun Phrases

\begin{tabular}{cc}
\hline Compounds & Noun Phrases \\
\hline greenhouse & green house \\
\hline
\end{tabular}




\begin{tabular}{cc}
\hline lightship & light ship \\
\hline crossword & cross word \\
\hline loudspeaker & loud speaker \\
\hline car-ferry & second class \\
\hline sunrise & bad-tempered \\
\hline suitcase & three-wheeler \\
\hline armchair & ice-cream
\end{tabular}

Table 5. Noun-Verb Pairs

\begin{tabular}{cc}
\hline Verbs & Nouns \\
\hline complement & complement \\
\hline compliment & compliment \\
\hline decrement & decrement \\
\hline document & document \\
\hline implement & implement \\
\hline supplement & supplement \\
\hline regiment & regiment \\
\hline import & import \\
\hline export & export
\end{tabular}

\subsection{Questionnaire}

To find out the pronunciation problems in terms of word stress placement, it was administered Questionnaire consisting of 5 choices. In this study, the students were asked to rate their perception by choosing one of the following choices which reveal how much he or she agrees or disagree by circling around. Strongly disagree (1), Disagree (2), Neither agree nor disagree (3), agree (4), and strongly agree (5).

\section{Findings and Discussion}

\subsection{Learners' Perception on English Word Stress}

The means and standard deviations of students' perception on English word stress are displayed in table 1. The findings indicate that the students achieved a mean of 3.5152 and SD $=.98046$ for LP-1 (Stress is one of the most difficult topics in phonology and pronunciation practice.). The students achieved a mean of 3.3788 and SD $=.75986$ for LP-2 (Stress on mono syllabic words is easy to identify.). The students achieved a mean of 3.3030 and SD $=.76399$ for LP-3 (Stress on two syllabic words is difficult to identify.). The students achieved a mean of 3.4697 and SD = -.237 for LP-4 (Stress on three syllabic words is difficult to identify.). The students achieved a mean of 3.5152 and SD $=.78920$ for LP-5 (Stress on four syllabic words is difficult to identify.). The students achieved a mean of 3.2727 and $\mathrm{SD}=.71351$ for LP-6 (Stress on words with prefixes is difficult to identify.). The students achieved a mean of 3.3182 and SD $=.66005$ for LP-7 (Stress on words with suffixes is difficult to identify). The students achieved a mean of 3.1818 and SD = .89286 for LP-8 (Stress on compound words is difficult to identify.). The students achieved a mean of 3.1970 and SD $=.86326 .86326$ for LP-9 (Stress on phrase is difficult to identify.). The students achieved a mean of 3.6061 and SD $=.87493$ for LP-10 (Learning correct stress placement needs large portion in EFL classroom.). 
ISSN: (E) 2621-0835, (P) 2621-0843

The students achieved a mean of 4.1515 and SD $=.68483$ for LP-11 (Correct stress placement on words is important.). The students achieved a mean of 2.6364 and SD $=1.06173$ for LP-12 (Incorrect stress placement on words is not important.). The students achieved a mean of 3.5758 and SD $=.76582$ for LP-13 (Stress placement needs to be taught at secondary schools as one of language elements.). The students achieved a mean of 4.1818 and SD $=.67730$ for LP-14 (Teaching stress needs more practices.). The students achieved a mean of 3.5909 and SD $=.89404$ for LP-15 (My stress placement on English words is sometimes influenced by my mother tongue.). Therefore, a normal distribution can be observed for all scales in the present study as revealed by skewness and kurtosis value as presented in table 6 .

Table 6. Learners' Perception (LP) on English Word Stress ( $N=166)$

\begin{tabular}{cccccccccc}
\hline Code & $\mathrm{M}$ & $\mathrm{SD}$ & Skewness & Kurtosis & $1(\%)$ & $2(\%)$ & $3(\%)$ & $\begin{array}{c}4 \\
(\%)\end{array}$ & $\begin{array}{c}5 \\
(\%)\end{array}$ \\
\hline LP-1 & 3.5152 & .98046 & .007 & -.971 & 0 & 16.7 & 33.3 & 31.8 & 18.2 \\
\hline LP-2 & 3.3788 & .75986 & -.117 & -.399 & 0 & 12.1 & 42.4 & 40.9 & 4.5 \\
\hline LP-3 & 3.3030 & .76399 & -.367 & -.813 & 0 & 16.7 & 37.9 & 43.9 & 1.5 \\
\hline LP-4 & 3.4697 & .82685 & -.237 & -.514 & 0 & 13.6 & 33.3 & 45.5 & 7.6 \\
\hline LP-5 & 3.5152 & .78920 & -.051 & -.353 & 0 & 9.1 & 39.4 & 42.4 & 9.1 \\
\hline LP-6 & 3.2727 & .71351 & -.717 & .292 & 0 & 1.5 & 10.6 & 47.0 & 40.9 \\
\hline LP-7 & 3.3182 & .66005 & -.119 & -.311 & 0 & 9.1 & 51.5 & 37.9 & 1.5 \\
\hline LP-8 & 3.1818 & .89286 & -.371 & -.389 & 3.0 & 19.7 & 36.4 & 37.9 & 3.0 \\
\hline LP-9 & 3.1970 & .86326 & .046 & -.891 & 0 & 24.2 & 36.4 & 34.8 & 4.5 \\
\hline LP-10 & 3.6061 & .87493 & -1.259 & 2.048 & 4.5 & 4.5 & 24.2 & 59.1 & 7.6 \\
\hline LP-11 & 4.1515 & .68483 & -.498 & .376 & 0 & 1.5 & 12.1 & 56.1 & 30.3 \\
\hline LP-12 & 2.6364 & 1.06173 & .465 & -.252 & 12.1 & 37.9 & 30.3 & 13.6 & 6.1 \\
\hline LP-13 & 3.5758 & .76582 & -.157 & -.242 & 0 & 7.6 & 36.4 & 47.0 & 9.1 \\
\hline LP-14 & 4.1818 & .67730 & -.544 & .526 & 0 & 1.5 & 10.6 & 31.8 & 31.8 \\
\hline LP-15 & 3.5909 & .89404 & -.948 & 1.586 & 4.5 & 3.0 & 31.8 & 50.0 & 10.6 \\
\hline
\end{tabular}

\subsection{The Stress Placement in Monosyllabic, Dissylabic, Trisyllabic, Stress in Affixes, Compounds and Noun Phrases, and Noun-Verb Pairs}

\subsubsection{The Recorded and Written Test}

The aim of this test is to investigate the correct and incorrect stress placement among the students of English department of Faculty of Languages and Literature State University of Makassar in reading a list of words and putting the main stress of those words.

As revealed in table 7 that all students or $100 \%$ were able to give correct stress placement of the target sound in the words. This result shows that Indonesian learners of English (ILE) have good mastery on putting a primary stress on monosyllabic words. This confirms the result of the questionnaire that the ILE feel easy to put the stress on one syllable word "Stress on mono syllabic words is easy to identify" with a mean of 3.3788 and SD $=.75986$. The theory says that if the stressable portion (SP) is monosyllabic, there is no choice of stress placement, the single stress receives stress (Fudge in Weda, 1998: 19). 
Table 7. The Stress Placement of One Syllable Word

\begin{tabular}{|c|c|c|c|c|c|c|}
\hline \multirow[t]{2}{*}{ Word } & \multirow[t]{2}{*}{$\begin{array}{l}\text { Target } \\
\text { Stress }\end{array}$} & \multirow{2}{*}{$\begin{array}{l}\text { Number } \\
\text { of } \\
\text { Students }\end{array}$} & \multicolumn{2}{|c|}{$\begin{array}{l}\text { Correct Stress } \\
\text { Placement (\%) }\end{array}$} & \multicolumn{2}{|c|}{$\begin{array}{c}\text { Incorrect Stress } \\
\text { Placement (\%) }\end{array}$} \\
\hline & & & Uttered & Written & Uttered & Written \\
\hline ship & ship & 66 & 100 & 100 & 0 & 0 \\
\hline eat & 'eat & 66 & 100 & 100 & 0 & 0 \\
\hline $\operatorname{man}$ & man & 66 & 100 & 100 & 0 & 0 \\
\hline
\end{tabular}

In table 8, the result reveals that the Indonesian learners of English (ILE) have good mastery in placing the stress on two syllable words. Above $70 \%$ of the stress placement are correct on two syllabic words in recording (utterance) test and almost all stress placements are correct on written test and they are above $60 \%$, only for the word permit is on $59.05 \%$. This shows that the number of students put the stress on the second syllable of the word which shows the incorrect stress placement. The results also show that the students were easy to put the correct stress placement in recording or pronouncing words than in writing down the primary stress on words. The theory says that if the stressable portion (SP) is disyllabic, stress is normally penultimate (Fudge in Weda, 1998: 19).

Table 8. The Stress Placement of Two Syllable Words

\begin{tabular}{ccccccc}
\hline Word & Target & \multirow{2}{*}{$\begin{array}{c}\text { Number } \\
\text { of }\end{array}$} & \multicolumn{2}{c}{$\begin{array}{c}\text { Correct Stress } \\
\text { Placement }(\%)\end{array}$} & \multicolumn{2}{c}{$\begin{array}{c}\text { Incorrect Stress } \\
\text { Placement (\%) }\end{array}$} \\
\cline { 4 - 7 } & Stress & Students & Uttered & Written & Uttered & Written \\
\hline Ozon & 'ozon & 66 & 93.93 & 80.30 & 6.06 & 10.60 \\
\hline Arab & 'Arab & 66 & 86.36 & 74.24 & 13.63 & 25.75 \\
\hline permit & 'permit & 66 & 98.48 & 59.09 & 1.51 & 40.90 \\
\hline apply & app'ly & 66 & 86.36 & 60.60 & 13.63 & 39.39 \\
\hline arrive & a'rrive & 66 & 95.45 & 71.21 & 4.54 & 28.78 \\
\hline attract & att'ract & 66 & 96.96 & 78.78 & 3.03 & 21.21 \\
\hline enter & 'enter & 66 & 98.48 & 77.27 & 1.51 & 22.72 \\
\hline equal & 'equal & 66 & 96.96 & 66.66 & 3.03 & 33.33 \\
\hline envy & 'envy & 66 & 95.45 & 77.27 & 4.54 & 22.72 \\
\hline follow & 'follow & 66 & 72.27 & 66.66 & 22.72 & 33.33 \\
\hline borrow & 'borrow & 66 & 87.87 & 68.18 & 12.12 & 31.81 \\
\hline
\end{tabular}

As seen from the table 9 below, only $9.0 \%$ of Indonesian learners of English (ILE) were able to pronounce word determine correctly in recording and $69.69 \%$ of ILE was able to write down the primary stress on the word determine. This shows that ILE was easy to put a primary stress on written test than place the stress on utterance. In pronouncing the word determine, ILE often put the primary stress on the third syllable. The results therefore show that ILE did not find difficulties on pronouncing and putting the stress placement on the other words in three syllable words as appeared on table 9 . This is because above $70 \%$ of utterance test and above $60 \%$ of written test are correct.

In verbs, if the last syllable contains a short vowel and ends with not more than one consonant, that syllable will be unstressed and stress will be placed on the penultimate syllable, like in en'counter and de'termine. The word 'determine' [de'termine] has the stress on the penultimate syllable. As previously stated that only 
ISSN: (E) 2621-0835, (P) 2621-0843

$9.0 \%$ of the ILE put correct stress placement on the word determine and others put primary stress on the last syllable.

Table 9. The Stress Placement of Three Syllable Words

\begin{tabular}{ccccccc}
\hline \multirow{2}{*}{ Word } & \multirow{2}{*}{$\begin{array}{c}\text { Target } \\
\text { Stress }\end{array}$} & \multirow{2}{*}{$\begin{array}{c}\text { Number } \\
\text { of } \\
\end{array}$} & & \multicolumn{2}{c}{$\begin{array}{c}\text { Correct Stress } \\
\text { Placement }(\%)\end{array}$} & \multicolumn{2}{c}{$\begin{array}{c}\text { Incorrect Stress } \\
\text { Placement (\%) }\end{array}$} \\
\cline { 4 - 7 } & & Students & Uttered & Written & Uttered & Written \\
\hline antelope & 'antelope & 66 & 72.27 & 66.66 & 22.72 & 33.33 \\
\hline cummerbund & 'cummerbund & 66 & 86.36 & 63.63 & 13.63 & 36.36 \\
\hline verandah & ve'randah & 66 & 98.48 & 74.24 & 1.51 & 25.75 \\
\hline spaghetti & spa'ghetti & 66 & 95.45 & 62.12 & 4.54 & 37.87 \\
\hline America & A'merica & 66 & 90.90 & 72.72 & 9.09 & 27.27 \\
\hline encounter & en'counter & 66 & 98.48 & 87.87 & 1.51 & 12.12 \\
\hline determine & de'termine & 66 & 9.09 & 69.69 & 90.90 & 30.30 \\
\hline entertain & enter'tain & 66 & 81.81 & 78.78 & 18.18 & 21.21 \\
\hline resurrect & resu'rrect & 66 & 83.33 & 75.75 & 16.66 & 24.24 \\
\hline potato & po'tato & 66 & 78.78 & 78.78 & 21.21 & 21.21 \\
\hline disaster & di'saster & 66 & 95.45 & 69.69 & 4.54 & 30.30 \\
\hline
\end{tabular}

Table 10. The Stress Placement of Words with Suffixes

\begin{tabular}{|c|c|c|c|c|c|c|}
\hline \multirow[t]{2}{*}{ Word } & \multirow[t]{2}{*}{ Target Stress } & \multirow{2}{*}{$\begin{array}{c}\text { Number } \\
\text { of } \\
\text { Students }\end{array}$} & \multicolumn{2}{|c|}{$\begin{array}{l}\text { Correct Stress } \\
\text { Placement (\%) }\end{array}$} & \multicolumn{2}{|c|}{$\begin{array}{l}\text { Incorrect Stress } \\
\text { Placement (\%) }\end{array}$} \\
\hline & & & Uttered & Written & Uttered & Written \\
\hline accuracy & 'accuracy & 66 & 80.30 & 46.96 & 19.69 & 53.03 \\
\hline anchorage & anchorage & 66 & 72.27 & 34.84 & 22.72 & 65.15 \\
\hline budgetary & 'budgetary & 66 & 59.09 & 42.42 & 40.90 & 57.57 \\
\hline disagreement & disa'greement & 66 & 93.93 & 54.54 & 6.06 & 45.45 \\
\hline politeness & po'liteness & 66 & 83.33 & 54.54 & 16.66 & 45.45 \\
\hline prestigious & prestigious & 66 & 72.72 & 40.90 & 27.27 & 59.09 \\
\hline advantageous & advanta'geous & 66 & 57.57 & 43.93 & 42.42 & 56.06 \\
\hline photography & pho'tography & 66 & 65.15 & 33.33 & 34.84 & 66.66 \\
\hline objectivity & objec'tivity & 66 & 43.93 & 19.69 & 56.06 & 80.30 \\
\hline modernist & 'modernist & 66 & 78.78 & 31.81 & 21.21 & 68.18 \\
\hline neighborhood & neighborhood & 66 & 72.72 & 12.12 & 27.27 & 87.87 \\
\hline
\end{tabular}

As revealed in table 10 that only $43.93 \%$ of ILE were able to pronounce word objectivity, they tend to put the stress on the second syllable for the word objectivity. In written test, only $19,69 \%$ of ILE were able to put the stress on correct stress placement. The ILE did not find difficulties on placing the primary stress on other words in words with suffixes in pronunciation (recording) test and the ILE were not able to put the correct stress placement on written test. Almost all words in the written test were below $50 \%$ of correct placement, only the word disagreement and politeness were above $50 \%$. This means the ILE were not able to identify the stress on written test. The ILE could not identify the correct stress placement on words with suffixes. 
Sukardi Weda. 1(3): $328-341$

The theory says that, when certain suffixes are attached to free forms (i.e. forms which can occur as words in their own right, they leave the stress-pattern unchanged. This kind of suffixes is inflectional and it is considered a stress-neutral suffix (Fudge in Weda, 1998: 27). There are some derivational suffixes also behave in this way; some are always stress-neutral (they do not affect the stress placement), like in words: comfortable ['comforbale], accuracy ['accuracy], anchorage ['anchorage] (Fudge in Weda, 1998: 27). There are some suffixes that influence stress in the stem, and the primary stress is on the last syllable of the stem, like in words: advantageous [advan'tageous], photography [pho'tography], objectivity [objec'tivity].

Table 11. The Stress Placement of Words with Prefixes

\begin{tabular}{|c|c|c|c|c|c|c|}
\hline \multirow[t]{2}{*}{ Word } & \multirow[t]{2}{*}{ Target Stress } & \multirow{2}{*}{$\begin{array}{l}\text { Number } \\
\text { of } \\
\text { Students }\end{array}$} & \multicolumn{2}{|c|}{$\begin{array}{l}\text { Correct Stress } \\
\text { Placement (\%) }\end{array}$} & \multicolumn{2}{|c|}{$\begin{array}{l}\text { Incorrect Stress } \\
\text { Placement (\%) }\end{array}$} \\
\hline & & & Uttered & Written & Uttered & Written \\
\hline improper & im'proper & 66 & 95.45 & 74.24 & 4.54 & 25.75 \\
\hline improbable & im'probable & 66 & 96.96 & 81.81 & 3.03 & 18.18 \\
\hline befriend & be'friend & 66 & 96.96 & 81.81 & 3.03 & 18.18 \\
\hline becalm & be'calm & 66 & 96.96 & 81.81 & 3.03 & 18.18 \\
\hline dislike & dis'like & 66 & 95.45 & 74.24 & 4.54 & 25.75 \\
\hline exservice & ex'service & 66 & 96.96 & 69.69 & 3.03 & 30.30 \\
\hline incorrect & inco'rrect & 66 & 96.96 & 69.69 & 3.03 & 30.30 \\
\hline illogical & illogical & 66 & 98.48 & 68.18 & 1.51 & 31.81 \\
\hline uncomfortable & un'comfortable & 66 & 72.72 & 63.63 & 27.27 & 36.36 \\
\hline irrational & ir'rational & 66 & 98.48 & 78.78 & 1.51 & 21.21 \\
\hline imbalance & im'balance & 66 & 50 & 77.27 & 50 & 22.72 \\
\hline
\end{tabular}

As illustrated on table 11 that only the word imbalance $(50 \%)$ and the word uncomfortable $(72.72 \%)$ were below $90 \%$ in recording or pronunciation test. This means that the ILE did not find difficulties in placing the primary stress on the words with prefixes in reading or uttering words with prefixes in recording test. In written test, all words were above $60 \%$ and this shows that the ILE were able to put the correct primary stress on words with prefixes in written test.

Certain prefixes, like stress-neutral suffixes, are automatically discounted when the placement of main stress is being calculated: main stress cannot possibly fall on them. They are not part of the stressable portion (SP) of the word. Thus the word 'proper' and 'probable,' if they are added with prefixes (im+proper, im+probable), the prefixes do not affect the stress placement or they are stressneutral prefixes (Fudge in Weda, 1998: 32).

Table 12. The Stress Placement of Compound Words

\begin{tabular}{llccccc}
\hline \multirow{2}{*}{ Word } & \multirow{2}{*}{$\begin{array}{c}\text { Target } \\
\text { Stress }\end{array}$} & $\begin{array}{c}\text { Number } \\
\text { of }\end{array}$ & \multicolumn{2}{c}{$\begin{array}{c}\text { Correct Stress } \\
\text { Placement (\%) }\end{array}$} & \multicolumn{2}{c}{$\begin{array}{c}\text { Incorrect Stress } \\
\text { Placement (\%) }\end{array}$} \\
\cline { 4 - 7 } & & 66 & 98.48 & 75.75 & 1.51 & 24.24 \\
\cline { 4 - 7 } greenhouse & 'greenhouse & 66 & Uttered & Written & Uttered & Written \\
\hline lightship & 'lightship & 66 & 98.48 & 74.24 & 1.51 & 25.25 \\
\hline crossword & 'crossword & 66 & 98.48 & 74.24 & 1.51 & 25.25 \\
\hline loudspeaker & 'loudspeaker & 66 & 98.48 & 71.21 & 1.51 & 28.78 \\
\hline car-ferry & 'car-ferry & 66 & 98.48 & 66.66 & 1.51 & 33.33 \\
\hline sunrise & 'sunrise & 66 & 98.48 & 59.09 & 1.51 & 40.90 \\
\hline
\end{tabular}


ISSN: (E) 2621-0835, (P) 2621-0843

\begin{tabular}{lllllll}
\hline suitcase & 'suitcase & 66 & 98.48 & 65.15 & 1.51 & 34.84 \\
\hline armchair & 'armchair & 66 & 98.48 & 68.18 & 1.51 & 31.81 \\
\hline
\end{tabular}

Table 12 above shows that the ILE was able to put the primary stress correctly on compound words, either in recording test or in written test. The ILE tended to put the stress placement correctly in recording test than in written test. Some ILE did not put the primary stress correctly in written test, especially for the word sunrise.

Table 13. The Stress Placement of Noun Phrases

\begin{tabular}{|c|c|c|c|c|c|c|}
\hline \multirow[t]{2}{*}{ Word } & \multirow[t]{2}{*}{$\begin{array}{l}\text { Target } \\
\text { Stress }\end{array}$} & \multirow{2}{*}{$\begin{array}{c}\text { Number } \\
\text { of } \\
\text { Students }\end{array}$} & \multicolumn{2}{|c|}{$\begin{array}{l}\text { Correct Stress } \\
\text { Placement (\%) }\end{array}$} & \multicolumn{2}{|c|}{$\begin{array}{c}\text { Incorrect Stress } \\
\text { Placement (\%) }\end{array}$} \\
\hline & & & Uttered & Written & Uttered & Written \\
\hline green house & $\begin{array}{l}\text { green } \\
\text { 'house }\end{array}$ & 66 & 96.96 & 69.69 & 3.03 & 30.30 \\
\hline light ship & light 'ship & 66 & 96.96 & 71.21 & 3.03 & 28.78 \\
\hline cross word & cross 'word & 66 & 96.96 & 59.09 & 3.03 & 40.90 \\
\hline loud speaker & $\begin{array}{l}\text { loud } \\
\text { 'speaker }\end{array}$ & 66 & 96.96 & 60.60 & 3.03 & 39.39 \\
\hline second class & $\begin{array}{l}\text { second } \\
\text { 'class }\end{array}$ & 66 & 96.96 & 60.60 & 3.03 & 39.39 \\
\hline bad-tempered & $\begin{array}{l}\text { bad- } \\
\text { tempered }\end{array}$ & 66 & 96.96 & 66.66 & 3.03 & 33.33 \\
\hline three-wheeler & $\begin{array}{l}\text { three- } \\
\text { 'wheeler }\end{array}$ & 66 & 96.96 & 62.12 & 3.03 & 37.87 \\
\hline ice-cream & ice-'cream & 66 & 96.96 & 53.03 & 3.03 & 46.96 \\
\hline
\end{tabular}

Table 13 above shows that the ILE was able to put the primary stress correctly on noun phrases, either in recording test or in written test. The ILE tended to put the stress placement correctly in recording test than in written test. The ILE were easy to put the correct stress on recording test than on written test.

Table 14. Stress on Verbs

\begin{tabular}{ccccccc}
\hline Word & \multirow{2}{*}{$\begin{array}{c}\text { Target } \\
\text { Stress }\end{array}$} & $\begin{array}{c}\text { Number } \\
\text { of }\end{array}$ & \multicolumn{2}{c}{$\begin{array}{c}\text { Correct Stress } \\
\text { Placement }(\%)\end{array}$} & \multicolumn{2}{c}{$\begin{array}{c}\text { Incorrect Stress } \\
\text { Placement (\%) }\end{array}$} \\
\cline { 4 - 7 } & & Students & Uttered & Written & Uttered & Written \\
\hline complement & comple'ment & 66 & 77.27 & 60.60 & 22.72 & 39.39 \\
\hline compliment & compli'ment & 66 & 77.27 & 60.60 & 22.72 & 39.39 \\
\hline decrement & decre'ment & 66 & 77.27 & 59.09 & 22.72 & 40.90 \\
\hline document & docu'ment & 66 & 77.27 & 56.06 & 22.72 & 43.93 \\
\hline implement & imple'ment & 66 & 77.27 & 50 & 22.72 & 50 \\
\hline supplement & supple'ment & 66 & 77.27 & 56.06 & 22.72 & 43.93 \\
\hline regiment & regi'ment & 66 & 77.27 & 54.54 & 22.72 & 45.45 \\
\hline import & im'port & 66 & 77.27 & 54.54 & 22.72 & 45.45 \\
\hline export & ex'port & 66 & 77.27 & 53.03 & 22.72 & 46.96 \\
\hline
\end{tabular}


Table 14 above shows that the ILE was able to put the primary stress correctly on stress on verbs, either in recording test or in written test. The ILE tended to put the stress placement correctly in recording test than in written test.

Table 15. Stress on Nouns

\begin{tabular}{ccccccc}
\hline \multirow{2}{*}{ Word } & \multirow{2}{*}{$\begin{array}{c}\text { Target } \\
\text { Stress }\end{array}$} & $\begin{array}{c}\text { Number } \\
\text { of } \\
\end{array}$ & & \multicolumn{2}{c}{$\begin{array}{c}\text { Correct Stress } \\
\text { Placement (\%) }\end{array}$} & \multicolumn{2}{c}{$\begin{array}{c}\text { Incorrect Stress } \\
\text { Placement (\%) }\end{array}$} \\
\cline { 3 - 6 } & & Uttered & Written & Uttered & Written \\
\hline complement & 'complement & 66 & 92.42 & 63.63 & 7.57 & 36.36 \\
\hline compliment & 'compliment & 66 & 92.42 & 60.60 & 7.57 & 39.39 \\
\hline decrement & 'decrement & 66 & 92.42 & 62.12 & 7.57 & 37.87 \\
\hline document & 'document & 66 & 92.42 & 62.12 & 7.57 & 37.87 \\
\hline implement & 'implement & 66 & 92.42 & 56.06 & 7.57 & 43.93 \\
\hline supplement & 'supplement & 66 & 92.42 & 60.60 & 7.57 & 39.39 \\
\hline regiment & 'regiment & 66 & 92.42 & 60.60 & 7.57 & 39.39 \\
\hline import & 'import & 66 & 92.42 & 60.60 & 7.57 & 39.39 \\
\hline export & 'export & 66 & 92.42 & 60.60 & 7.57 & 39.39 \\
\hline
\end{tabular}

Table 15 above shows that the ILE was able to put the primary stress correctly on stress on nouns, either in recording test or in written test. The ILE tended to put the stress placement correctly in recording test than in written test.

\section{Conclusions}

Some conclusions can be drawn from this study. Firstly, the Indonesian learners of English (ILE) were able to put the an acute accent (') illustrating the primary stress on monosyllabic words (one syllable words); two syllable words, except for word permit; three syllable words, except for the word determine; words with suffixes in reading test; words with prefixes, except for word imbalance; compound words, except for word sunrise; noun phrases; stress on verbs and stress on nouns. In written test, the ILE were not able to put an acute accent (') symbolizing the main stress on polysyllabic words with suffixes, except for the words objectivity and disagreement.

Secondly, the ILE tended to put the correct stress placement on recording or reading test than on written test for the list of words. The ILE pronounce the words spontaneously and they found difficulties on putting the stress placement in written test. In polysyllabic words, like: permit, determine, imbalance, accuracy, anchorage, etc., the ILE often mistress the words. This confirmed by the results of the questionnaires that 'Stress on three syllabic words is difficult to identify' with a mean of 3.4697 and SD $=-.237$, 'Stress on four syllabic words is difficult to identify' with a mean of 3.5152 and SD $=.78920$, 'Stress on words with prefixes is difficult to identify' with a mean of 3.2727 and $S D=.71351$, and 'Stress on words with suffixes is difficult to identify' with a mean of 3.3182 and $S D=.66005$.

Finally, the educational implication of this study is that the practice for stress placement of words, ranging from dissyllabic words to polysyllabic words needs to be toiled in English learning and teaching process in the classroom setting. The teaching of pronunciation: stress placement needs to be taught at primary and secondary 
schools. This in keeping with the results of the questionnaires that 'Learning correct stress placement needs large portion in EFL classroom' with a mean 3.6061 and SD $=.87493$ and 'Correct stress placement on words is important' with a mean of 4.1515 and SD $=.68483$.

The study therefore suggests to other researchers to make research on other topics in pronunciation problems like intonation.

\section{References}

Archibald, J. (1994). A Longitudinal Study of the Acquisition of English Stress. Paper presented at the Canadian Association of Applied Linguistics. Calgary, May 1994, pp. 1-10.

Checklin, M. (2012). What in the World Do We Know about Word Stress? A Review of What It Is and How to Teach It. TESOL in Context, Special Edition S3, pp. $1-13$.

Crystal, D. (1987). A Dictionary of Linguistics and Phonetics. New York: Basil Blackwell Ltd.

Dieu, T.T.T. (2015). A Case Study of Solutions to Some Intonation Mistakes Made by Vietnamese Students - A Phonetic Experimental Research. International Journal of Language and Linguistics, 3(2): 52-60, pp. 52-60.

Flege, J.E \& Bohn, O. S. (1989). An Instrumental Study of Vowel Reduction and Stress Placement in Spanish-Accented English. SSLA. 11, pp. 35-62

Fromkin, V, Rodman, R, \& Hyams, N. (2007). An Introduction to Language. Boston: Thomson Wadsworth.

Gralinska, B \& Rybinska. (2017). The Relationship between the Production of Word Stress and Musical Abilities in Polish Learners of English. Research in Language, 2017, vol. 15:3, pp. 265-283.

Guion, S.G, Harada, Tetsuo, \& Clark, J.J. (2004). Early and Late Spanish - English Bilinguals of English Word Stress Patterns. Bilingualism: Language and Cognition, 7(3), pp. 207-226.

Guion, S.G. (2005). Knowledge of English Word Stress Patterns in Early and Late Korean-English Bilinguaals. SSLA, 27, pp. 503-533.

Herndon, J. (1976). A Survey of Modern Grammars. New York: Holt, Rinehart and Winston.

Karjo, C. (2016). Accounting for L2 Learners' Errors in Word Stress Placement. Indonesian Journal of Applied Linguistics, 5(2), pp. 199-208.

Kawagoe, I. (2002). Acquisition of English Word Stress by Japanese Learners. Proceedings of the 6th Generative Approaches to Second Language Acquisition Conference (GASLA 2002), ed. Juana M. Liceras et al., pp. 161167

Liu, D. (2017). The Acquisition of English Word Stress by Mandarin EFL Learners. English Language Teaching, Vol. 10, No. 12, pp. 196-201.

Moerdjito. (2008). Perceptions of the Seriousness of Mispronunciations of English Speech Sounds. TEFLIN Journal, Volume 19, Number 1, February 2008, pp. 70-92.

Sabater, M.J.S. (1991). Stress and Rhythm in English. Revista Alicantina de Estudios Ingleses 4 (1991): 145-62, pp. 145-162.

Wayland, R, Guion, Susan, G, Landfair, David, \& Li, B. (2006). Native Thai Speakers' Acquisition of English Word Stress Patterns. J Psycholinguist Res (2006) 35, pp. 285-304. 
Sukardi Weda. 1(3): $328-341$

Weda, S. (1998). Interlanguage Phonology: Stress Shifts of English Utterances Made by Indonesian Speakers of English. Unpublished Thesis Universitas Hasanuddin.

Weda, S. (2012). Stress Shifts of English Utterances Made by Indonesian Speakers of English (ISE). International Journal of English Linguistics, Vol. 2, No. 4 August 2012.

Weda, S \& Sakti, A.E.F. (2017). The Effects of Formal Instruction on the Acquisition of English Short Vowels. International Journal of Science and Research (IJSR), Volume 6, Issue 5, May 2017, pp. 3643-3647.

Weda, S \& Sakti, A.E.Fadhilah. (2017). The Effects of Formal Instruction on the Acquisition of English Fricative Consonants of Indonesian EFL Learners. Researchers World - Journal of Arts, Science \& Commerce, Vol. -VIII, Issue 2 (1), April 2017, pp. 14-27.

Weda, S \& Sakti, A.E.F. (2018). The Effects of Formal Instruction on the Acquisition of English Long Vowels. Journal of Physics: Conf. Series 1028 (2018) -012101, pp. 1-5. 